\title{
A comparative Analytical Studies onAcaciapolyacantha gum Samples collected from three different locations in Sudan
}

\author{
Elgaili. A. Omer ${ }^{1,2}$, Abdulaziz. A. Alomari ${ }^{\star 2}$, Mohammed. E. Osman ${ }^{3}$, Ahmed A. El- \\ Henawy 2,4 \\ 1Deanship of Graduate Studies and Scientific Research, Kassala University, P.O.Box 266, Kassala.Sudan. \\ ${ }^{2}$ Department of chemistry, Faculty of Science and Arts ,Al-Mukhwah,ALbahaUniversity,Kindom of Saudi Arabia. \\ ${ }^{3}$ Sudan University of Science \&Technology Khartoum, Sudan. \\ ${ }^{4}$ Chemistry Dept. Faculty of Science (Boys), Al-Azhar University, Nasr City, Cairo, Egypt.
}

Author to whom correspondence should be addressed; - Mail: elhenawy_sci@hotmail.com.;Tel.: +966503779064.

\section{Summary}

Acacia polyacanthagum(Kakamut gum) samples were collected as natural exudates, from three different locations in Sudan named Abugarin, Gargadah and Layoon forest. Physicochemical properties of gum samples were studied (moisture , ash ,nitrogen , protein, specific rotation, intrinsic viscosity , refractive index, equivalent weight, $\mathrm{pH}$, uronic acid and reducing sugars . Results showed significant differences within each location in most parameters studied, refractive index values were found to be constant in all samples (1.3337). The effect of location on the properties of gum samples was studied and the analysis showed generally insignificant difference $(p \geq 0.05)$ in all properties studied, except moisture and uronic acid showed significant differences. The general characteristics of Acacia gum might be described as a mean value of all properties studied of all gum samples of the three different locations as follows ; $8.3 \%$ moisture, $2.9 \%$ ash ,0.35\%nitrogen, $2.30 \%$ protein, $-16.8 \stackrel{\circ}{\circ}$ specific rotation, $10.3 \mathrm{ml} / \mathrm{g}$ intrinsic viscosity, $4.9 \mathrm{pH}, 1348.68$ equivalent weight, $14.5 \%$ uronic acid, 1.3337 refractive index and $0.20 \%$ reducing sugar. UV absorption spectra of gum samples were determined and the maximum absorption points were found the same ranging between wavelength (208 and $211 \mathrm{~nm}$ ) . The cationic composition of gum samples was also determined and the results showed that sodium $(43.075 \mathrm{ppm})$ has the highest value in all samples followed by iron(27.667ppm), zinc(14.297ppm), nickel(4.650ppm), copper(4.025), manganese $(2.645 \mathrm{ppm})$, calcium(1.284ppm) and trace amount of lead(0.667ppm), potassium( $0.344 \mathrm{ppm})$ and magnesium $(0.274 \mathrm{ppm})$. Accordingly, these parameters, therefore, cannot be recommended as qualifying indices.

Keywords: Kakamut; UV- absorption; nitrogen content; acidity; minerals and reducing sugars.

\section{Council for Innovative Research}

Peer Review Research Publishing System

\section{Journal: Journal of Advances in Natural sciences}

\author{
Vol. 1, No. 1 \\ editorjansonline@gmail.com \\ www.cirworld.com
}




\section{Introduction}

The term gum often describe materials which affect the sense of touch, taste and sight in summed up as property of "gummosis" which is difficult to define but visual and manual examination of the material may cause the observer to call it gum [1]. Gum refers to any polysaccharide that is dispersible in water to give viscous solution, gels or colloidal dispersions(Anderson1994). Generally gums are long chain, high molecular weight, polymers that dissolve or disperse in water to give thickening gelling effect and exhibit related secondary functional properties, such as emulsification , stabilization, and encapsulation(Sharma1981). Gums, or hydrocolloids, are mainly long - chain, straight to branched polysaccharides that contain hydroxyl groups that can bond to water molecules .

These chains consist of (2000 to 10000) monosaccharide's units, the sugars monomers may contained linked side units , or substituent groups, such as sulphates, methyl ethers, esters and acetates (Kuntz 1990). Gums composed mainly of C, $\mathrm{H}, \mathrm{O}$ and $\mathrm{N}$ elements(Mantell1965), and the acidic gums (e.g. gumarabic) contain mainly $\mathrm{Ca}, \mathrm{Mg}, \mathrm{Na}$ and Fe as cations (Hirst 1965). Specifications are quality indices which are set to characterize the nature of the gums, since gum arabic is the most important species used in food products and a wide range of the range of other industrial application. According to Anderson(1986) in order to identify a particular gum from a series of different gum exudates an extensive number of analytical tests have to be performed. This approach enable a finger print of each gum to be determined, the currently analytical test used include determination of the total ash, nitrogen (hence protein), measurements of optical rotation , intrinsic viscosity, equivalent weight, analysis neutral sugars (arabinose, rhamnose and galactose) and glucuronic acid content after hydrolysis and measurement of molecular mass. Since international trade requires vigorous quality control specifications to identify the product and trace any adulteration processes, it is essential that firm parameters are established for the gum property of gum arabic. According to American Food Chemical Codex, the specification for identity and purity of gum arabic were published in 1978(Karamalla 1998), and it has been reviewed every 4 years (JECFA,

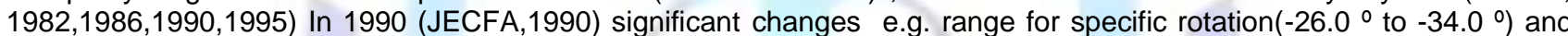
nitrogen content (0.27 to $0.39 \%$ ) were introduced. However, in 1995 JECFA further recommended that specific rotation and nitrogen content be deleted.

The mostly important property of a gum which make it unique amongst polysaccharides generally it is solubility and viscosity. The majority of gums dissolve in water at different concentration(e.g. Gum arabic can form solutions of up to $60 \%$ forming viscous solutions). These properties of gums can be utilized in many applications, such as in food industry which is the major one, where emulsifying and stabilizing properties are utilized. The gum is also used in the pharmaceutical and medical fields, in addition to other industries (cosmetic, adhesive, paints and inks). Gum from Acacia polyacantha tree is a dried exudation obtained from stem and branches of Acacia polyacanthatree ,family(Leguminusae) and genus(Acacia), English name is Falcon's claw acacia and arabic name (Kakamut, Umsinina) (Alamin,1977 and Voget, 1995). Kakamut tree is widely distributed in Africa throughout tropical Africa.

In Sudan there are several regional varieties, which usually occur along rivers and valleys where the water table is fairly high and soils are good(Voget 1995). In Sudan Acacia polyacantha tree is widely spread in Upper Nile province, Kordofan province and Blue Nile province.

The wood is used mainly in fuel and charcoal of good quality, fence posts, farm implements and railway, sleeper, beams, and rafters. The gum is edible and used as adhesive in the treatment of textile fibers. The roots are used to act as a general health tonic as antidote for snake bite, and cure for venereal diseases. A preparation from the bark is used for general stomach disorders(Voget1995).The aim of this work is to present and evaluate analytical data of authentic gum samples collected from three different locations, also to find out the effect of location on the gum properties.

\section{Results and Discussion}

The moisture content of Abugarin samples was found to be in the range $(6.3-9.5 \%)($ Table1), while Gargadah samples ranged from(6.8to10.6\%) ( Table2), Layoon samples(Table3) ranged between (6.1 to 9.6\%). Analysis of variance showed that within one location there is a significant difference $(p \leq 0.05)$ in each of Abugarin and Gargadah samples where as insignificant differences $(p \leq 0.05)$ were observed in Layoon samples. Table 4 showed significant effect of location on moisture content. However the mean value of moisture content of all samples in the three locations is(8.3\%). It is illustrated that the mean value for moisture content is in the range of senegal gum (8.1 to $14.04 \%)$ as reported by Karamalla(1998), it was less than the range (9.4 to11.6\%) of polyacantha gum reported by Siddig(2003), and it is in close agreement with the mean value (8.5\%) for Acacia polyacantha gum reported by Abdelsalam(1998). This findings is less than the recent results (10.3\%) for Acacia Polyacantha gum reported by Elnouret.al(2009). Ash content of Abugarin samples ranged between(1.9 and 3.6\%) (Table 1).Gargadah samples ranged from (2.5to3.9\%)(Table 2) and Layoon samples ranged from $(2.0 \%$ to $3.3 \%)$ (Table 3$)$. Analysis of variance with location observed insignificant differences ( $p \leq$ $0.05)$ for all samples. Location insignificantly affected the ash content (Table 4). The mean value of ash content of samples from the three different locations was( $2.9 \%)$. The range of ash content of Acacia polyacantha gum was closer to the result mentioned by Elkhatim(2001) forpolyacantha gum (2.8\%), and also is in agreement with the mean value(2.9)reported by Abdelsalam(1998). This result is less than that (3.3\%) for Acacia polyacantha gum reported by Elnour(2007).

Table 1 showed the nitrogen content of Abugarin samples, which ranged from( 0.32 to $0.40 \%)$ and hence the protein content ranged from(2.11 to $2.44 \%)$. Table 2 showed that nitrogen content of Gargadah samples $(0.39$ to $0.40 \%)$ and protein content of (2.57 to $2.60 \%$ ). The values of nitrogen content for Layoon samples ranged from $(0.31$ to $0.39 \%)$ and protein content ranged between(2.05to2.57\%)respectively, (Table3). Insignificant difference ( $p \leq 0.05$ ) in nitrogen and hence protein contents was observed for all samples observed in analyzed data of nitrogen and protein contents of 
Abugarin, Gargadah and Layoon samples Table (4). The mean value of nitrogen content and protein content of all samples, from the three different locations, was $(0.35 \%)$ and $(2.31 \%)$ respectively. Nitrogen and protein content of $A$. polyacanthagum samples are in agreement with that reported for Acacia polyacantha gum $(0.35 \%)$, (2.30\%) by Karamalla(1965), it is also in a close agreement with the mean value of nitrogen (0.34\%), protein(2.24\%) of Acacia senegal reported by Ishag(1977). It was within the range of nitrogen and protein content $(0.33-0.36 \%, 2.2-2.4 \%)$ of $A c a c i a$ polyacantha gum reported by Karamalla(1998) and Elkhatim(2001).Such results obtained, it was also in the range (0.30 to $0.42 \%)$ for nitrogen and (1.88 to $0.42 \%$ ) for protein in the recent studies reported by Elnour et.al(2009).

Aqueous solutions of all samples were found to be optically active (laevorotatory). Table $\mathbf{1}$ showed that the specific rotation of Abugarin samples ranged from $\left(-7.0^{\circ}\right.$ to $\left.-22.5^{\circ}\right)$, while specific rotation of Gargadah samples ranged from( $14.5^{\circ}$ to $\left.-26.0^{\circ}\right)$ (Table 2), and Layoon samples ranged from $\quad\left(-11.5^{\circ}\right.$ to $\left.-20.5^{\circ}\right)$ (Table 3). Within one location analysis of variance showed insignificant differences $(p \leq 0.05)$ between all samples. Table 4 showed that there is insignificant effect of location in specific rotation of Acacia. polyacantha gum samples of the three different locations is less than the range $\left(-24.5^{\circ}\right.$ to $\left.-36.7^{\circ}\right)$ for Acacia.senegalreported by Siddig(1996), and higher than Acacia polyacantha gum values of $\left(-7^{\circ}\right)$ and $\left(-13^{\circ}\right)$ showed by Siddig(2003), also is greater than the result for Acacia polyacantha $\left(-10.3^{\circ}\right)$ reported by Biswas(2000). These findings, it is in the range $\left(-8.7^{\circ}\right.$ to $\left.-25.0^{\circ}\right)$ reported by Elnour et.al(2009). Aqueous solutions of all samples of Acacia polyacantha gum showed low viscosity. Table 1 showed that the intrinsic viscosity of Abugarin samples ranged from (10.2 to $10.4 \mathrm{ml} / \mathrm{g}$ ), andGargadah samples ranged from (10.0 to $10.6 \mathrm{ml} / \mathrm{g})$ (Table2). Layoon samples are in the range of $(10.2$ to $10.5 \mathrm{ml} / \mathrm{g}$ ) (Table 3$)$.Analysis of variance within location showed insignificant difference $(p \leq 0.05)$ in each; also location was found to be insignificantly affecting the intrinsic viscosity of all samples was $(10.3 \mathrm{ml} / \mathrm{g})$. The intrinsic viscosity of Acacia polyacantha gum was closer to the result obtained by Siddig(2003) for Acacia polyacantha gum $(12.7 \mathrm{ml} / \mathrm{g})$, and less than $(14 \mathrm{ml} / \mathrm{g})$ for Acacia seyal reported by Elkhatim(2001), it was also in a close agreement with the recent results $(10.2 \mathrm{ml} / \mathrm{g}$ ) reported by Elnour(2007).

The $\mathrm{pH}$ of aqueous solution of all samples indicated the acidity of Acacia polyacantha gum which may be due to the presence of acidic sugars (Glucuronic acids) Table 1 showed that the $\mathrm{pH}$ of Abugarin samples is in the range of (4.6to 5.2), and Gargadah samples were in the range of (4.5 to 5.2) (Table 2), and Layoon samples were in the range(4.7 to 5.0$)$ (Table3).Analysis of variance indicated that within locations there is insignificant difference $(\mathrm{p} \leq 0.05)$ in the $\mathrm{pH}$ value and so location did not affect the $\mathrm{pH}$ of the gum (Table 4). The mean value of $\mathrm{pH}$ of the gum samples in the three locations was found to be( 4.9), and it was in agreement with that range value (3.19 to 5.61) of Acacia senegalgum reported by Karamalla( 1998),this result is closely related to the value(5.96) of Acacia polyacantha gum reported by Elnour et.al(2009). Refractive index of all samples from the three different locations is found to be constant having the value (1.3337) (Table 1,2, and 3), and so there is no effect of location in the value of the refractive index (Table4). The refractive index was in a close agreement with results of the refractive index of Acacia polyacantha gum (1.3339) reported by Elkhatim(2001). Table1 showed that the equivalent weight of Abugarin samples ranged between (1166.41to1552.80),and Gargadah samples ranged from (1111.11 to 1358.70), Table (2) and that of Layoon samples ranged from (1111.11 to 1619.87), Table (3). Analysis of variance showed insignificant differences $(p \leq 0.05)$ in all samples. However the effect of location on equivalent weight showed insignificant differences (Table 4), and the mean value of equivalent weight of samples in the three locations were (1348.68). This value is in agreement with that range(1136.0 to 1875) for Acacia senegal gum reported by Karamalla(1998), it was also greater than the recent studies of Acacia polyacantha gum(1280.80) represented by Elnour(2007).

Concerning the presence of uronic acids in all samples of Acacia polyacantha gum indicated that all samples have acidic sugar (glucuronic acids), uronic acid contents of Abugarin samples ranged from (12.49 to 16.63\%) (Table1), Gargadah samples ranged from(14.28to17.46\%) (Table2), Layoon samples ranged from (11.98 to $17.05 \%$ ) (Table3). Analysis of variance showed that within one location there is a significant differences $(p \leq 0.05)$ in each of Gargadah and Layoon samples, where as insignificant differences $(p \leq 0.05)$ were observed in Abugarin samples. Table 4 showed that location significantly affected uronic acid contents, and the mean value of the three location samples is (14.61\%), which was in the range of Acacia senegal gum (10.34\% -23.32\%) reported by Siddig(1996), and it is in close agreement with mean value of AnogesissusLeiocarpus gum (14.3\%)reported by Eltayeb(1999,2009). Reducing sugars of Acacia polyacantha gum was calculated as Arabinose (Fig.1) and the presence of reducing sugar gives evidence to the reducing power (free reducing groups) of this type of gum. Reducing sugar content of Abugarin samples is in the range of $(0.10$ to $0.54 \%)($ Table 1$)$ Gargadah samples is in the range of (0.10 to $0.46 \%)$ (Table 2), and that of Layoon samples ranged from $(0.10$ to $0.36 \%)$ (Table 3). Analysis of variance shows insignificant differences within location. The mean value of reducing sugar of all samples is $(0.20 \%)$, which is in agreement with that of Acacia senegal gum(0.16-0.44\%) reported by Anderson(1966) .The above result is less than the result $(0.44 \%)$ for AnogesissusLeiocarpus gum reported by Eltayeb(2009).

Fig. 2, 3 and 4showed UV absorption of Acacia polyacantha gum obtained from Abugarin, Gargadah and Layoon respectively. It has been observed that the maximum absorption points are approximately same(4.1)ranging between the wavelength $(208-211 \mathrm{~nm})$, and this may proved to be a diagnostic feature and therefore an apparent analytical parameter for Acacia polyacantha gum.

Cationic composition of Acacia polyacantha gum from three different locations was determined using atomic absorption spectrophotometer, are represented in Table 5Abugarin gum samples showed decreasing trends in metal ions for $\mathrm{Na}>$ $\mathrm{Fe}>\mathrm{Zn}>\mathrm{Cu}>\mathrm{Ni}>\mathrm{Mn}>\mathrm{Ca}>\mathrm{Pb}>\mathrm{K}>\mathrm{Mg}$ and in Gargadah for $\mathrm{Na}>\mathrm{Fe}>\mathrm{Zn}>\mathrm{Ni}>\mathrm{Cu}>\mathrm{Ca}>\mathrm{Mn}>\mathrm{Pb}>\mathrm{K}>\mathrm{Mg}$, while $\mathrm{Layoon}$ gum ions represented a decreasing trends as $\mathrm{Na}>\mathrm{Fe}>\mathrm{Zn}>\mathrm{Cu}>\mathrm{Mn}>\mathrm{Ca}>\mathrm{Pb}>\mathrm{Ni}>\mathrm{K}>\mathrm{Mg}$. It is observed that sodium $(\mathrm{Na})$ has higher value in the three different locations, it is also revealed that Acacia polyacantha gum may be a source of iron $(\mathrm{Fe})$ and this indicates the nutritive values of this gum. 


\section{Experimental}

Moisture \%, ash\%, pH,viscosity and specific rotation were determined according to $\mathrm{FAO}(1990$ a,b) paper No. 44 and 49 . Nitrogen was determined by semi- micro khjeldahlmethods(AOAC .1984) and the protein content was determined by multiplying nitrogen percent by the factor 6.6(Anderson . 1986). Equivalent weight was determined according to methods reported in the Encyclopedia of Chemical Technology(1966). Reducing sugars were determined according to method reported by Robert and White(1987) and maximum absorption spectra of $1 \%$ gum solution were determined by using a Perkin - Elmer Lambda 2 UV/Vis Spectrophotometer. Minerals were determined using a Perkin - Elmer -2380 Atomic absorption Spectrophotometer.

\section{Statistical analysis}

Each sample was analyzed chemically in triplicate and data was assessed by Analysis of Variance(ANOVA) (Snedecor and Cochran. 1987), comparative analyses between samples were carried out by Least Square Differences(LSD) multiple range tests to determine significant of differences in a appropriate means at probability $(p \leq 0.05)$

\section{Conclusion}

We have successively studied different physicochemical properties of Acacia polyacantha gum collected from three locations (Abugarin, Gargadah and Layoon). Studying the effect of locations on all parameters were found to be insignificantly difference $(P \leq 0.05)$. These properties of the gum from three different locations confirmed the hetropolymolecular nature of the gum, such results, it agrees with Anderson(1966b). Thus it has been concluded that Acacia polyacantha gum is a hetropolymolecular polymer consisting of molecules that differ in their mode of linkage as well as in molecular mass.

\section{Acknowledgements}

We would like to express our deepest appreciation and sincere respects to the Gum Arabic Company (Ltd) Staff for their help. We wish to thank Dr. Muntasir.A.Osman for his help throughout this study.Special thanks to the Staff of Industrial Research and Consultancy for their help throughout this study.

\section{REFERENCES}

[ 1] Mantell,C.L(1947)"The water- soluble gums "Reinhold, Publishing Corp Academic Press, New York.

[2] Anderson,D.M.W(1994). The Chemistry and Industry of Forest products, vol. 14, 3,67.

[3] Sharma, S.C(1981) .Gums and Hydrocolloids in oil water Emulsions . Food Technology (59-67)

[4] Kunz , A. L(1990). Food Product Design. Application Special Effect with Gums . Week Publishing Company .

[5] Mantell, C.L (1965)"The water- soluble gums "Reinhold, Publishing Corp Academic Press, New York.

[6] Anderson, D. M .W (1986); Nitrogen conversion factors of the proteinaceous content of gums permitted as food additives and contaminants; 3, $231-234$.

[7] Karamalla, A.K, N.E. Siddig, M.E. Osman(1998). Analyticaldata for A. senegal var. senegalGum Samples Collected Between 1993 and 1995 from Sudan. Food Hydrocolloids, 12,pp. 373-378.

[9] JECFA- FAO(1982).Specifications for identity and purity of certain food additive Food Nutrition paper No.25, Rome.

[10] JECFA- FAO(1986).Specifications for identity and purity of certain food additive .Food Nutrition paper No.34, Rome.

[11] JECFA- FAO(1990).Specifications for identity and purity of certain food additive .Food Nutrition paper No. 49 Rome

[12] JECFA- FAO(1990).Specifications for identity and purity of certain food additive .Food Nutrition paper No. 44 Rome

[13] JECFA-FAO(1995).Compendium of food additive specification, Addendum 3,No, 52 Rome .

[14] Amin ,H.M(1977).Forest Administration, Forest Research Institute , Bulletin, No. 2,Khartoum. Sudan

[15] Voget , K(1995) . Common Trees and Shrubs of Dry land . Sudan, London

[16] Siddig, N. E (2003). Characterization, Fractionation studies on some Acacia gums. Ph. D .Thesis University of Khartoum. Sudan.

[17] Abdelsalam, Z(1998). Gum Exudates as Taxonomy for classification of Some Sudan Acacia's .M.Sc . Thesis, Faculty of Science, University of

[18] Elnour,A.H, M.E. Osman, K.A.E. Ishag, H.E. Adam(2009).Pysicochemical properties of Acacia Polyacantha Gum.Conference on International Research on Food Security, Natural Resourse Management and Rural Development.Tropentag.University of Hamburg. 
[19] Elkhatim,K.S(2001).Factors affecting the emulsifying properties of some Acacia gums. M.Sc.Thesis University of Khartoum, Sudan.

[20] Elnour,A.H(2007).Fractionation ;Physicocmical and Functional properties of Acacia Polyacantha gum . M.Sc.Thesis University of Khartoum,Sudan.

[21] Karamalla. A. K (1965). Analytical and structural studies in the polysaccharide group. Ph. D .Thesis. University of Edinburgh. UK.

[21]Khogali. A. Ishag (1977). Ishag. K .A (1977), Chemotaxonomic Studies on Sudan Acacias Ph. D. Thesis. U of Khartoum. Sudan.

[22] Siddig, N.E. (1996). Nitrogen and Specific Rotation as Quality Indicesfor Gum Arabic Derived from A. senegal. M.Sc. Thesis University of Khartoum. Sudan

[23] Biswas. S, Biswas. S \&Phillips.O.P(2000). The relationship of specific rotation to structural composition for Acacia and related gums Food hydrocolloids 14, 601-608 Food chemistry, 41, 71-77.

[24] Eltayeb.S.A(1999).Analytical Studies on the gum exudates from Anogeissus Leiocarpus, Ph.D. Thesis University of .Khartoum, Sudan.

[25] Anderson,D.M.W, K.A Karamalla(1966) Studies on uronic acid materials . Part (XII).The composition of Acacia Gum exudates. Journal ofChem.Soc., 8: 762.

[26] Eltayeb, S.A, B.E. Mohamed,A.K. Karamalla(2009). Analytical Studies on the gum exudates from AnogeissusLeiocarpus, Pakistan Journal of Nutrition 1680-5194, 8(6):pp 782-786.

[27]FAO(1990). Specifications for identity and purity of certain food additive .Food Nutrition paper No. 445, Rome.

[28] A.O.A.C(1984). Association of Official Agriculture Chemists, $14^{\text {th }}$ edn, Washington. D.C.

[29] Anderson. D. M .W (1986); Nitrogen conversion factors of the proteinaceous content of gums permitted as food additives and contaminants; $3,231-234$.

[30] Encyclopedia of chemical technology(1966).Vol 2, Executive and Editor Anthony Stander, inter science, publishers John Willely and Son Inc London.UK.

[31] Robert,J.F , B. J. White (1987) . Biochemical techniques theory and practices brooks/ Cole publishing Company.

[32] Snedecorm. W,W.G.Cochran(1987).Statistical Methods. Oxford IBH Publishing Co. Ltd. New Delhi, pp: 20 -35.

Table .1. The analytical data of different Acacia polyacantha gum samples from Abugarin

\begin{tabular}{|c|c|c|c|c|c|c|c|c|c|c|c|}
\hline Sample & Moisture\% & Ash\% & Nitrogen\% & Protein\% & $\begin{array}{l}\text { Specific } \\
\text { rotation }\end{array}$ & $\begin{array}{c}\text { Intrinsic } \\
\text { viscosity } \\
(\eta)(\mathrm{ml} / \mathrm{gm})\end{array}$ & $\mathrm{pH}$ & $\begin{array}{c}\text { Refractive } \\
\text { index }\end{array}$ & $\begin{array}{l}\text { Equivalent } \\
\text { Weight }\end{array}$ & $\begin{array}{l}\text { Uronic } \\
\text { acid\% }\end{array}$ & $\begin{array}{l}\text { Reducing } \\
\text { sugar\% }\end{array}$ \\
\hline As1 & 9.5 & 3.5 & 0.34 & 2.24 & $-13.0^{\circ}$ & 10.4 & 4.8 & 1.3337 & 1304.34 & 14.87 & 0.13 \\
\hline As2 & 6.5 & 2.2 & 0.35 & 2.31 & $-7.0^{\circ}$ & 10.4 & 4.6 & 1.3337 & 1453.49 & 13.35 & 0.13 \\
\hline As3 & 6.3 & 3.0 & 0.32 & 2.11 & $-13.5^{\circ}$ & 10.4 & 4.8 & 1.3337 & 1425.86 & 13.61 & 0.13 \\
\hline As4 & 7.2 & 3.1 & 0.32 & 2.11 & $-17.0^{\circ}$ & 10.4 & 5.0 & 1.3337 & 1329.79 & 14.59 & 0.31 \\
\hline As5 & 7.0 & 2.3 & 0.37 & 2.44 & $-20.5^{\circ}$ & 10.2 & 5.0 & 1.3337 & 1327.43 & 14.61 & 0.54 \\
\hline As6 & 8.5 & 3.6 & 0.35 & 2.31 & $-22.0^{\circ}$ & 10.4 & 5.2 & 1.3337 & 1231.53 & 15.75 & 0.46 \\
\hline As7 & 9.0 & 3.0 & 0.32 & 2.11 & $-22.5^{\circ}$ & 10.3 & 5.0 & 1.3337 & 1166.41 & 16.63 & 0.10 \\
\hline As8 & 7.0 & 2.2 & 0.32 & 2.11 & $-15.5^{\circ}$ & 10.2 & 5.0 & 1.3337 & 1327.43 & 14.61 & 0.10 \\
\hline As9 & 7.2 & 1.9 & 0.37 & 2.44 & $-16.5^{\circ}$ & 10.3 & 4.7 & 1.3337 & 1552.80 & 12.49 & 0.10 \\
\hline As10 & 8.0 & 3.3 & 0.35 & 2.31 & $-13.5^{\circ}$ & 10.2 & 4.9 & 1.3337 & 1363.64 & 13.58 & 0.13 \\
\hline Mean & 7.6 & 2.8 & 0.34 & 2.25 & $-16.1^{\circ} \stackrel{0}{ }$ & 10.3 & 4.9 & 1.3337 & 1348.27 & 14.71 & 0.21 \\
\hline S.E \pm & 0.0341 & 0.1925 & 0.0064 & 0.0424 & 1.4996 & 0.0291 & 0.0558 & 0.0000 & 34.8010 & 0.3940 & 0.0520 \\
\hline
\end{tabular}

${ }^{*}$ As = Abugarin sample. Each value in the table is a mean of three replicates . E.S = Standard error. 
Table. 2. The analytical data of different Acacia polyacantha gum samples from Gargadah

\begin{tabular}{|c|c|c|c|c|c|c|c|c|c|c|c|}
\hline Sample & Moisture\% & Ash\% & Nitrogen\% & Protein\% & $\begin{array}{l}\text { Specific } \\
\text { rotation }\end{array}$ & $\begin{array}{c}\text { Intrinsic } \\
\text { viscosity } \\
(\eta)(\mathrm{ml} / \mathrm{gm})\end{array}$ & $\mathrm{pH}$ & $\begin{array}{l}\text { Refractive } \\
\text { index }\end{array}$ & $\begin{array}{c}\text { Equivalent } \\
\text { Weight }\end{array}$ & $\begin{array}{l}\text { Uronic } \\
\text { acid\% }\end{array}$ & $\begin{array}{l}\text { Reducing } \\
\text { sugar\% }\end{array}$ \\
\hline Gs1 & 9.1 & 2.5 & 0.32 & 2.11 & $-26.0^{\circ}$ & 10.4 & 4.5 & 1.3337 & 1223.49 & 15.86 & 0.13 \\
\hline Gs2 & 6.8 & 3.0 & 0.30 & 1.98 & $-15.0^{\circ} \stackrel{\circ}{ }$ & 10.0 & 4.8 & 1.3337 & 1308.90 & 14.82 & 0.10 \\
\hline Gs3 & 8.7 & 3.8 & 0.37 & 2.44 & $-19.0^{\circ} \stackrel{\circ}{ }$ & 10.3 & 5.0 & 1.3337 & 1264.76 & 15.34 & 0.14 \\
\hline Gs4 & 9.1 & 3.9 & 0.39 & 2.57 & $-18.5^{\circ}$ & 10.3 & 4.5 & 1.3337 & 1239.67 & 15.65 & 0.14 \\
\hline Gs5 & 9.0 & 2.8 & 0.39 & 2.57 & $-20.0^{\circ}$ & 10.4 & 4.7 & 1.3337 & 1266.89 & 15.31 & 0.14 \\
\hline Gs6 & 9.5 & 2.8 & 0.35 & 2.31 & $-16.0^{\circ} \stackrel{\circ}{ }$ & 10.6 & 4.8 & 1.3337 & 1273.34 & 15.24 & 0.10 \\
\hline Gs7 & 10.5 & 2.7 & 0.32 & 2.11 & $-16.5^{\circ}$ & 10.3 & 4.9 & 1.3337 & 1245.85 & 15.57 & 0.31 \\
\hline Gs8 & 7.6 & 2.7 & 0.40 & 2.64 & $-14.5^{\circ}$ & 10.4 & 5.2 & 1.3337 & 1358.70 & 14.28 & 0.46 \\
\hline Gs9 & 10.6 & 3.0 & 0.40 & 2.64 & $-20.0^{\circ} \stackrel{\circ}{0}$ & 10.3 & 4.6 & 1.3337 & 1111.11 & 17.46 & 0.36 \\
\hline Gs10 & 9.0 & 3.0 & 0.40 & 2.64 & $-15.0^{\circ} \stackrel{0}{ }$ & 10.4 & 4.8 & 1.3337 & 1315.79 & 14.74 & 0.36 \\
\hline Mean & 9.0 & 3.0 & 0.36 & 2.40 & $-18.1^{\circ}$ & 10.3 & 4.8 & 1.3337 & 1260.85 & 14.43 & 0.22 \\
\hline S.E \pm & 0.3647 & 0.1474 & 0.0122 & 0.0806 & 1.1042 & 0.0476 & 0.0696 & 0.0000 & 20.9763 & 0.2708 & 0.0423 \\
\hline
\end{tabular}

- Gs=Gargadah sample. Each value in the table is a mean of three replicates .S. E= Standard error.

Table. 3. The analytical data of different Acacia polyacantha gum samples from Layoon (forest)

\begin{tabular}{|c|c|c|c|c|c|c|c|c|c|c|c|}
\hline Sample & Moisture\% & Ash\% & Nitrogen\% & Protein\% & $\begin{array}{l}\text { Specific } \\
\text { rotation }\end{array}$ & $\begin{array}{c}\text { Intrinsic } \\
\text { viscosity } \\
(\mathrm{n})(\mathrm{ml} / \mathrm{gm})\end{array}$ & $\mathrm{pH}$ & $\begin{array}{c}\text { Refractive } \\
\text { index }\end{array}$ & $\begin{array}{c}\text { Equivalent } \\
\text { Weight }\end{array}$ & $\begin{array}{l}\text { Uronic } \\
\text { acid\% }\end{array}$ & $\begin{array}{c}\text { Reducing } \\
\text { sugar\% }\end{array}$ \\
\hline Ls1 & 8.7 & 3.0 & 0.31 & 2.05 & $-16.5^{\circ}$ & 10.2 & 4.9 & 1.3337 & 1530.61 & 12.67 & 0.10 \\
\hline Ls2 & 8.6 & 2.9 & 0.34 & 2.24 & $-20.5^{0}$ & 10.2 & 4.9 & 1.3337 & 1619.87 & 11.98 & 0.13 \\
\hline Ls3 & 8.7 & 2.0 & 0.35 & 2.31 & $-19.0^{\circ}$ & 10.5 & 4.8 & 1.3337 & 1619.87 & 11.98 & 0.13 \\
\hline Ls4 & 7.0 & 3.2 & 0.32 & 2.11 & $-13.0^{\circ}$ & 10.5 & 4.8 & 1.3337 & 1453.49 & 13.35 & 0.13 \\
\hline Ls5 & 7.9 & 3.2 & 0.32 & 2.11 & $-11.5^{\circ}$ & 10.4 & 5.0 & 1.3337 & 1595.74 & 12.16 & 0.13 \\
\hline Ls6 & 7.9 & 3.0 & 0.32 & 2.11 & $-12.0^{\circ}$ & 10.2 & 5.0 & 1.3337 & 1494.02 & 12.75 & 0.13 \\
\hline Ls7 & 6.1 & 2.6 & 0.35 & 2.31 & $-14.0^{\circ}$ & 10.4 & 4.7 & 1.3337 & 1536.89 & 12.62 & 0.13 \\
\hline Ls8 & 9.6 & 3.1 & 0.32 & 2.11 & $-18.0^{\circ}$ & 10.5 & 4.7 & 1.3337 & 1262.63 & 15.36 & 0.36 \\
\hline Ls9 & 9.5 & 3.3 & 0.39 & 2.57 & $-20.5^{\circ}$ & 10.3 & 4.8 & 1.33337 & 1145.04 & 16.94 & 0.36 \\
\hline Ls10 & 9.6 & 3.1 & 0.39 & 2.57 & $-17.0^{\circ}$ & 10.4 & 5.0 & 1.3337 & 1111.11 & 17.05 & 0.13 \\
\hline Mean & 8.4 & 2.9 & 0.34 & 2.25 & $-16.2^{\circ}$ & 10.4 & 4.9 & 1.3337 & 1436.93 & 13.69 & 0.17 \\
\hline SE \pm & 0.3658 & 0.1195 & 0.0092 & 0.0606 & 1.0729 & 0.0400 & 0.0371 & 0.0000 & 61.1183 & 0.6326 & 0.0031 \\
\hline
\end{tabular}

${ }^{*}$ Ls= Layoonsample ,each value in the table is a mean of three replicates .S.E= Standard error

Table. 4 . Effect of location on physico-chemical properties of Acacia polyacantha gum

\begin{tabular}{|c|c|c|c|c|c|c|c|c|c|c|c|}
\hline Sample & Moisture\% & Ash\% & Nitrogen\% & Protein\% & $\begin{array}{l}\text { Specific } \\
\text { rotation }\end{array}$ & $\begin{array}{l}\text { Intrinsic viscosity } \\
(\eta)(\mathrm{ml} / \mathrm{gm})\end{array}$ & $\mathrm{pH}$ & $\begin{array}{l}\text { Refractive } \\
\text { index }\end{array}$ & $\begin{array}{c}\text { Equivalent } \\
\text { Weight }\end{array}$ & $\begin{array}{l}\text { Uronic } \\
\text { acid\% }\end{array}$ & $\begin{array}{l}\text { Reducing } \\
\text { sugar\% }\end{array}$ \\
\hline Abugarin & 7.6 & 2.8 & 0.34 & 2.25 & $-16.1^{\circ}$ & 10.3 & 4.9 & 1.3337 & 1348.27 & 14.71 & 0.21 \\
\hline Gargadah & 9.0 & 3.0 & 0.36 & 2.40 & $-18.1^{\circ}$ & 10.3 & 4.8 & 1.3337 & 1260.85 & 14.43 & 0.22 \\
\hline Layoon & 8.4 & 2.9 & 0.34 & 2.25 & $-16.2^{\circ}$ & 10.4 & 4.9 & 1.3337 & 1436.93 & 13.69 & 0.17 \\
\hline Mean & 8.3 & 2.9 & 0.35 & 2.30 & $16.8^{\circ}$ & 10.3 & 4.9 & 1.3337 & 1348.68 & 14.61 & 0.20 \\
\hline S.E \pm & 0.2549 & 0.1531 & 0.0093 & 0.0612 & 1.2256 & 0.0389 & 0.5442 & 0.0000 & 38.9652 & 0.4325 & 0.0325 \\
\hline Sig-value & 0.039 & 0.637 & 0.166 & 0.165 & 0.467 & 0.777 & 0.317 & 0.000 & 0.302 & 0.038 & 0.395 \\
\hline
\end{tabular}

* Each value in the table is a mean of three replicates, S.E = Standard error,Sig-value=significant value. 
Table 5 Minerals contents of Acaciapolyacanthagum (ppm)

\begin{tabular}{|l|l|l|l|l|l|l|l|l|l|l|}
\hline Sample & $\mathrm{Mg}$ & $\mathrm{Ca}$ & $\mathrm{Na}$ & $\mathrm{K}$ & $\mathrm{Zn}$ & $\mathrm{Cu}$ & $\mathrm{Pb}$ & $\mathrm{Mn}$ & $\mathrm{Fe}$ & $\mathrm{Ni}$ \\
\hline Abugarin & 0.098 & 0.554 & 46.125 & 0.221 & 12.265 & 3.425 & 0.500 & 2.075 & 24.650 & 3.400 \\
\hline Gargadah & 0.370 & 1.991 & 36.975 & 0.446 & 18.955 & 5.950 & 0.500 & 1.675 & 25.600 & 9.950 \\
\hline Layoon & 0.354 & 1.308 & 46.125 & 0.365 & 11.670 & 2.700 & 1.000 & 2.185 & 32.750 & 0.600 \\
\hline Mean & 0.274 & 1.284 & 43.075 & 0.344 & 14.297 & 4.025 & 0.667 & 2.645 & 27.667 & 4.650 \\
\hline S.E \pm & 0.0881 & 0.4150 & 3.0500 & 0.0658 & 4.3354 & 0.9850 & 0.1667 & 0.1550 & 3.0918 & 2.7705 \\
\hline
\end{tabular}

*Each value in the table is a mean of three replicates

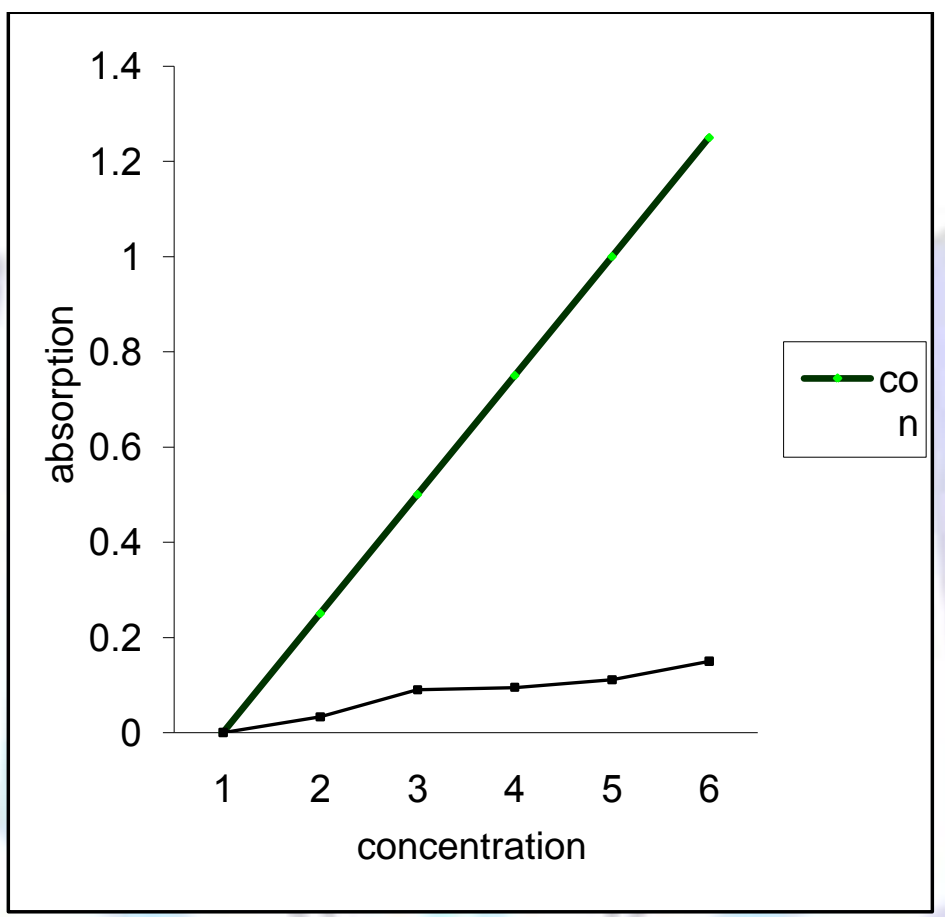


Fig.1. Standard curve for reducing sugar concentration (as Arab

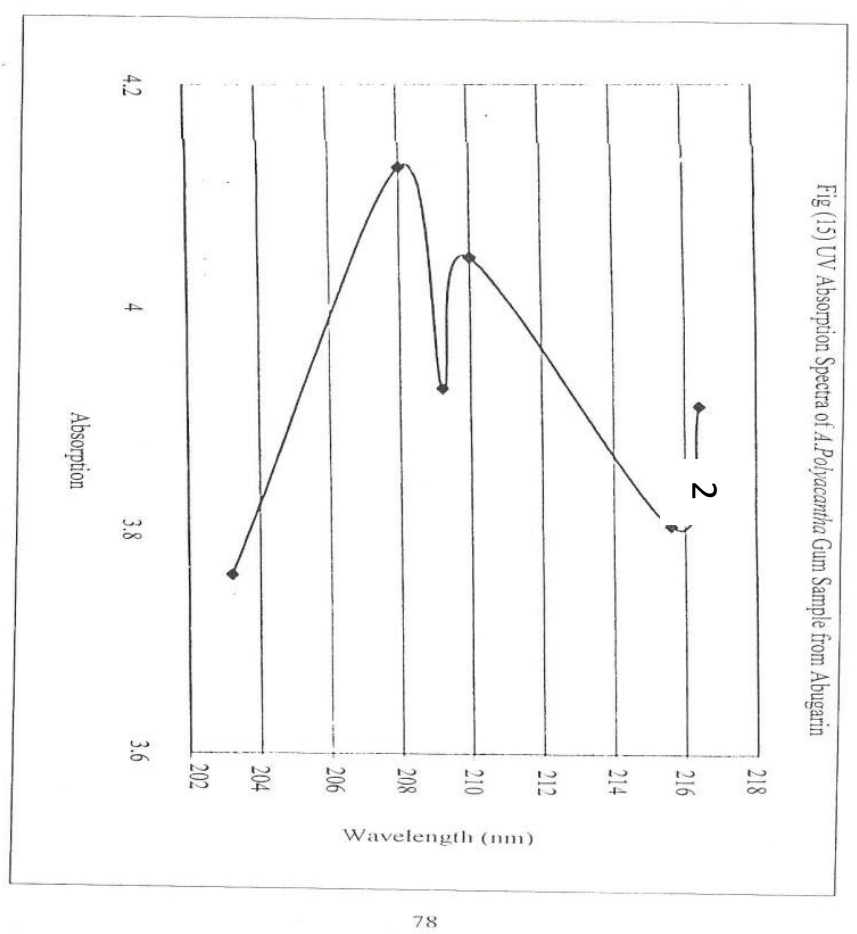



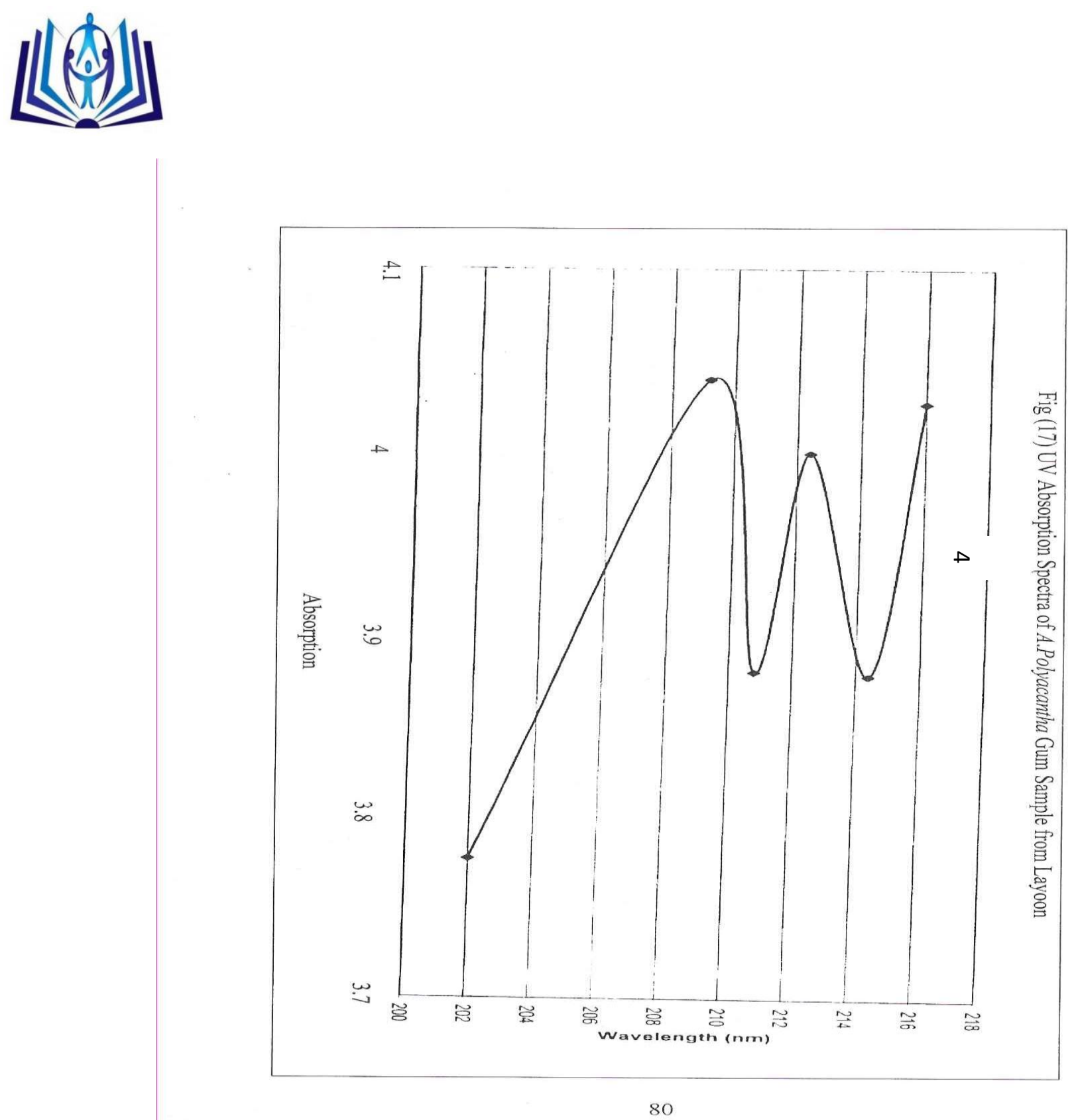